\title{
MS32-P10 | Structural Landscape of Cu(II) CoORdination Compounds With Isomers ANd Derivatives of CyClic TriImidazole
}

Melnic, Elena (Institute of Applied Physics, Chisinau, MDA); Kravtsov, Victor (Institute of Applied Physics, Chisinau, MDA); Lucenti, Elena (Istituto di Scienze e Tecnologie Molecolari - Consiglio Nazionale delle Ricerche and INSTM UdR,, Milano, ITA); Cariati, Elena (INSTM-UdR Milano, Dipartimento di Chimica, Università degli Studi di Milano, Milano, ITA); Forni, Alessandra (Istituto di Scienze e Tecnologie Molecolari del CNR(ISTM-CNR),INSTM-UdR, Milano, ITA); Fonari, Marina (Institute of Applied Physics, Chisinau, MDA)

The interest in functional coordination compounds is motivated by their potential applications in materials science associated with properties of both inorganic and organic constituents. The cyclic triimidazo[1,2- $a: 1^{\prime}, 2^{\prime}-c: 1^{\prime \prime}, 2^{\prime \prime}$ e] $[1,3,5]$ triazine, $L_{1}$, emissive in the solid state due to stacking interactions and formation of $\mathrm{H}$-aggregates, was documented as a multidentate ligand capable to assemble $\mathrm{Cu}(\mathrm{I})$ halide coordination networks with emissive and NLO behaviour (Licenti et al., 2017; 2019). Starting from copper(II) nitrate or acetate salts and four triimidazole ligands including $L_{1}$, its positional isomer, triimidazo[1,2-a:1', $\left.2^{\prime}-c: 1^{\prime \prime}, 5^{\prime \prime}-e\right][1,3,5]$ triazine, $L_{2}$, and two isomeric pyridine-substituted derivatives, $\mathrm{L}_{3}$ and $\mathrm{L}_{4}$, eight $\mathrm{Cu}(\mathrm{II})$ compounds are reported: four mono- $\left(\left[\mathrm{Cu}\left(\mathrm{L}_{2}\right)_{4}\left(\mathrm{NO}_{3}\right)_{2}\right] \cdot \mathrm{dmf}\right.$, 1, $\left[\mathrm{Cu}\left(\mathrm{L}_{2}\right)_{4}\left(\mathrm{NO}_{3}\right)_{2}\right] \cdot \mathrm{CH}_{3} \mathrm{CN}, \quad$ 2, $\left.\left[\mathrm{Cu}\left(\mathrm{L}_{2}\right)_{2}\left(\mathrm{CH}_{3} \mathrm{COO}\right)_{2}\right], \quad 3, \quad\left[\mathrm{Cu}\left(\mathrm{L}_{4}\right)_{2}\left(\mathrm{NO}_{3}\right)_{2}\left(\mathrm{H}_{2} \mathrm{O}\right)_{2}\right] \cdot \mathrm{H}_{2} \mathrm{O}, \quad 4\right)$, two dinuclear $\left(\left[\mathrm{Cu}_{2}\left(\mathrm{~L}_{1}\right)_{2}\left(\mathrm{CH}_{3} \mathrm{COO}\right)_{4}\right], 5\right.$, and $\left[\mathrm{Cu}_{2}\left(\mathrm{~L}_{3}\right)_{2}\left(\mathrm{CH}_{3} \mathrm{COO}\right)_{4}\right], 6$ complexes, and two $1 \mathrm{D}$ coordination polymers, $\left(\left\{\left[\mathrm{Cu}_{2}\left(\mathrm{~L}_{2}\right)\left(\mathrm{CH}_{3} \mathrm{COO}\right)_{4}\right]_{2}\left[\mathrm{Cu}_{2}\left(\mathrm{~L}_{2}\right)\left(\mathrm{CH}_{3} \mathrm{COO}\right)_{4} \mathrm{H}_{2} \mathrm{O}\right] 2\left(\mathrm{H}_{2} \mathrm{O}\right)\right\}_{n}, 7\right.$, and $\left\{\left[\mathrm{Cu}\left(\mathrm{L}_{3}\right)\left(\mathrm{NO}_{3}\right)_{2}\right]\right\}_{n}, 8$. The $\mathrm{Cu}(\mathrm{II})$ atom in 1-4 has either $\mathrm{N}_{4} \mathrm{O}_{2}$ or $\mathrm{N}_{2} \mathrm{O}_{4}$ square-bipyramidal coordination cores. Complexes 5-6 include paddle-wheel acetate dimers capped by $L_{1}$ or $L_{3}$ in axial positions. In the zigzag-like coordination polymer $\mathbf{7}$ the acetate paddle-wheel dimers, interlinked by bridging $\mathrm{L}_{2}$ ligand, coordinate via axial positions to $\mathrm{Cu}(\mathrm{II})$ atoms by different $\mathrm{N}$-binding sites, being associated in the crystal with discrete $\left[\mathrm{Cu}_{2}\left(\mathrm{~L}_{2}\right)\left(\mathrm{CH}_{3} \mathrm{COO}\right)_{4} \mathrm{H}_{2} \mathrm{O}\right]$ dinuclear units. In $8, \mathrm{~L}_{3}$ coordinates the metal atom in a chelate mode, while nitrate anions coordinate the metal in a chelate and bidentate bridging modes. The ligands' stacking motifs are traced and discussed. Studies on the emissive properties of selected compounds are currently underway.

Acknowledgments: The financial support from bilateral Moldova/Italy project 18.80013.16.03.03/It and ASM-CNR 2018-2019 project is acknowledged. 